\title{
Governmental Research Support Programs and Private Entities in Slovakia ${ }^{1}$
}

\section{Zuzana Maliková2, Matúš Kubák ${ }^{3}$, Radovan Bačík ${ }^{4}$, Miloš Fišar ${ }^{5}$}

\begin{abstract}
The paper analyses public subsidies aimed to enhance development and innovation in the Slovakian private sector. The paper reviews theoretical approaches of the necessity of public support to research and development activities in order to increase private investment in research and development. An overview of research and development support tools in Slovakia is presented. The analytical part of the work is oriented on a comparative analysis of two granting agencies in Slovakia [Agency for Research and Development (ARD) and Agency of Operational Program Research and Development (OPRD)]. Special attention is given to direct public financial support. Logit analysis showed a relationship between success of grant applicants and their characteristics. We find that the following have impact on success of the application: Age of the company, amount of the grant required, legal form of the company, and the agency to which the application for grant was submitted. Applicants with legal form Ltd. (limited liability company) have a higher chance of receiving grant than other legal forms. The highest chance of success has a request for a grant of up to $500.000 €$. According to the results of our analysis, the chance to obtain a grant decreases with each passing year.
\end{abstract}

Key words: research, development, innovation, subsidy, logit regression, Slovakia

JEL Classification: C52, C59, O31, O32, Q55

\section{Introduction}

Innovations as an important factor of economic growth are not only mentioned in growth theories, but their significance is also confirmed by the current situation in which decisions of governments at the level of the European Union are focused on creating a knowledge-based society concentrated on innovation and science and research as the primary factors of competitiveness of the European Union. 2010 was the final year for the Lisbon strategy of 2000, the main goal of which was to make the European Un-

\footnotetext{
${ }^{1}$ The contribution was made thanks to the project VEGA 1/0726/14.

2 Aupark Shopping Center Košice, Nám. Osloboditel'ov 1, 04001 Košice, Slovakia, malikova.zuzana@gmail.com

${ }^{3}$ Technical University of Košice, Faculty of Economics, Němcovej 32, 04001 Košice, Slovakia, matuskubak@gmail.com.

${ }^{4}$ University of Prešov in Prešov, Faculty of Management, Konštantínova 16, 08001 Prešov, Slovakia,radovan.bacik@unipo.sk.

${ }^{5}$ Masaryk University, Faculty of Economics and Administration, Lipová 41a, 60200 Brno, Czech republic,milos.fisar@econ.muni.cz.
} 
ion "the most competitive and knowledge-based economy in the world capable of steady sustainable growth" by 2010 (Government office, 2010). Lately, Europe has been falling behind the U.S.A. and China in terms of innovation and initiative (Kuncl, 2010). The Lisbon strategy suggested that this goal be achieved through increased investment in science, research and innovations at the level of 3\% of GDP, while at least two-thirds of this sum should come from the private sector. Concerning information from other data of the Eurostat database from 2010, estimated expenditures of the European Union (27 countries) on development of science and research represent $2 \%$ of GDP with $1.23 \%$ of this sum coming from the private sector. An excess of the estimated 3\% of GDP was achieved only in Finland with $3.87 \%$ of GDP, Sweden with $3.42 \%$ of GDP (in 2008 it was $3.7 \%$ ), and Denmark with $3.06 \%$ of GDP. The failure to reach the goals of the Lisbon strategy has led to creation of a new document called "Strategy 2020" which defines five goals: Promoting and supporting employment, research and innovations; change of climate and energy; promoting education, and fighting poverty (Europa, 2010). The aim regarding science and research remained the same in the strategy of the European Union 2020 as in the previous strategy, according to which the expenses spent on research and progress should reach $3 \%$ of GDP.

As far as countries of European Union are concerned, their innovation activities are monitored by the European Commission through the Summary innovation index. Summary innovation index describes the total relative innovation performance of the countries; based on this, the countries are divided into four groups : Innovation leaders (Denmark, Finland, Germany and Sweden), Innovation followers (Austria, Belgium, Cyprus, Estonia, France, Ireland, Luxembourg, the Netherlands, Slovenia, and the United Kingdom), Moderate innovators (the Czech Republic, Greece, Hungary, Italy, Malta, Poland, Portugal, Slovakia, and Spain) and Modest innovators (Bulgaria, Lithuania, Latvia, and Romania) (European Commission, 2011).

The group of the Moderate innovators includes member states of the EU where the innovation performance is below the innovation performance of the EU average. In Moderate innovators group, policies and funding toward science are often too skewed and leave very little for support of business research, development and innovation. These countries have, in principle, less absorption capacity for businesses to innovate. Countries in this group focus their research on different areas. Slovakia and Lithuania focus on innovations in science and business research, development and innovation. This means that countries focus on competitive research and development programs, and are not using research and development tax incentives. The Czech Republic, Hungary, Spain, Portugal focus on business research and development and innovation, which means that these countries aim at direct business research and development; business innovation; and use of research and development tax incentives. Italy focuses on technology transfer mechanisms, strong support for entrepreneurship, loans and venture capital and extensive use of research and development tax incentives. Greece focuses on collaborative research and development; support for loan and venture capital funds; and no use of research and development tax incentives. Malta focuses on competitive research and development programs with an increasing share of business innovation support measures and use of research and development tax incentives (European Commission, 2013). 
Slovakian innovative system is described in Figure 1. Despite the fact that the National Council of the Slovak Republic is the only constitutional and legislative body of the Slovak Republic, prime position in determining of the rules of the game in research and science in Slovak Republic is possessed by Ministry of Education, Science, Research and Sport of the Slovak Republic. This ministry governs state aid and funding for both basic and applied research and experimental development. The ministry is thus the only competent authority to manage the entire complex of science and technology in Slovakia. Science and technology policy is fulfilled through its departments, especially through section of science and technology and section of higher education. Implementation of research and development funding is then partially executed directly by the internal departments of the ministry of education and partly by its grant agency - Agency for Research and Development ("Science and Technology Policy", n.d.).

In 2007, Slovakia validated the "Long-term Aim of the National Scientific and Technological Policy by 2015" which determines the conditions needed for the development of science and technology. Its goal is to increase the concern of science and technology in the overall development of the Slovak Republic. In order to achieve the goals of the long-term intention in 2008, Slovakia confirmed the "Strategy of Completing the Longterm Plan of the National Scientific and Technological Policy by 2015" for the period until 2010. The long-term aim was updated by the "Phoenix Strategy" ("Science and Technology Policy”, n.d.) in 2011.

Figure 1 National Scientific, Technological and Innovative Policy Management of Slovakia

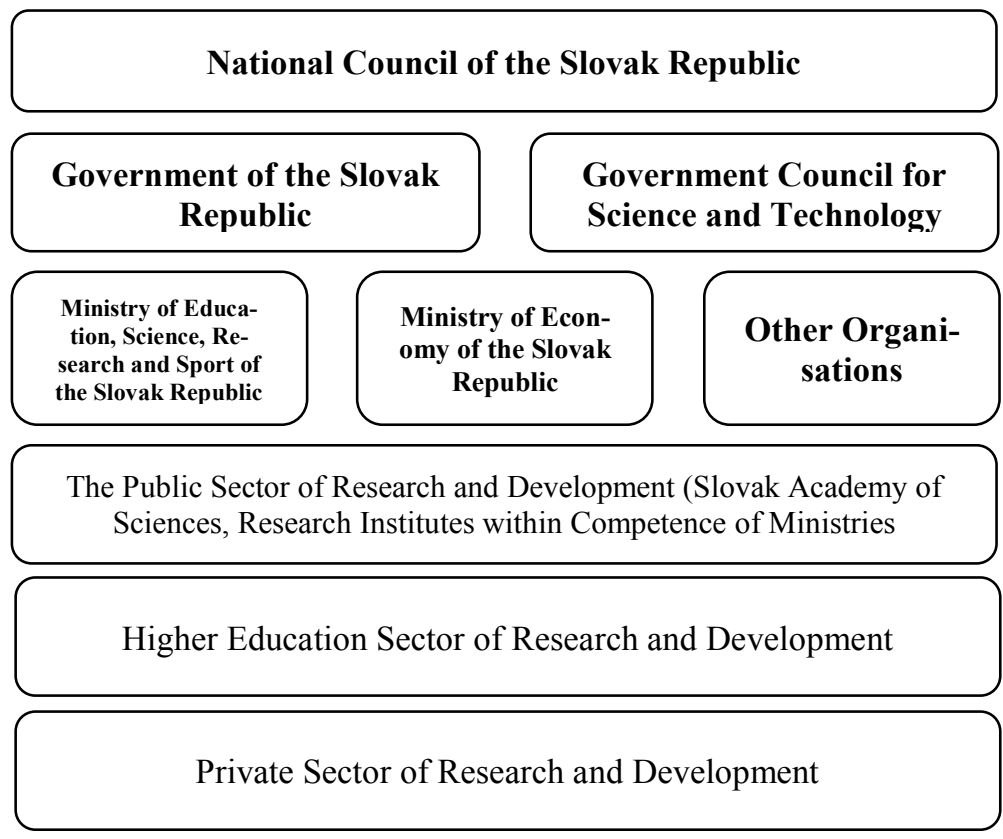

Source: Authors 
The goal of the Innovation Strategy of Slovakia for the period of 2007-2013 was "for innovations to become one of the main tools of development of knowledge-based economy as well as ensure the high economic growth of the Slovak Republic with the aim to reach the level of the most developed economies in the European Union" (MOE, 2007). In 2006, the Ministry of Economy of the Slovak Republic carried out an analysis of innovation policy which led to the exposal of several deficiencies (Prno, 2008). Poor innovativeness of companies is caused by a general lack of knowledge, human capital and lack of funds. Apart from the mentioned, the analysis also revealed two most significant reasons for low private investments into research and development. Companies innovate insufficiently because they lack venture capital. The second reason is that Slovak companies actually attach only small importance to innovation. The results of this analysis affected the formulation of the National Strategic Reference Framework for the years 2007 to 2013 .

As Slovak companies often lack funds, they frequently need to decide whether they should develop new products and services and therefore carry out research and development activities, or rather just are the providers of services and products. This fact also proves the need of state support for research and development because, as the Arrow (1962 ) claims, low return on investment can act as a disincentive and discourage from performing further research and development activities. In addition to this, Levin (1987) and Mansfield (1991) pointed out in their studies that even imitation of a new invention is not cheap. According to the results of Mansfield, imitation can cost anything from 50\% to $75 \%$ of the costs put into the original inventiveness. State support should serve at least as a temporary bypass of resource gaps; let us say to pay the staff of the research department.

At the moment, there is a widespread awareness of difficulties connected with obtaining grants as one of the forms of state support to stimulate research and development. Some applicants point out that unnecessary bureaucracy, complicated financial rules and especially vague and unclear conditions of distribution of grants are creating distrust in the distribution system. Corruption and cronyism are perceived as important facts in the process of obtaining grants. According to the report of Minerva 2.06 ARD (Agency for Research and Development), it neither works efficiently ((MoF, 2011, p.15), nor does it create optimal financial programs, objectivity and transparency during the selection of highest quality projects. Apart from that, the authors of the report point out that there is an unpredictability of promulgating financial programs because agencies concentrate more on uniformity of distribution of grants than on the performance of supported projects (Minerva).

Slovakia suffers from a lack of analysis of direct state support impact. Examination investigating whether direct financial support has a complementary or substitution effect is usually carried out in developed countries with a high percentage of investments in research and development of GDP. State support for research and development of pri-

\footnotetext{
${ }^{6}$ Minerva is the official government program of development of the knowledge-based economy in Slovakia.
} 
vate subjects raises the question of whether or not financial support has the substitution effect or complementary effect. Complementary effect means that companies will extend their innovative activities through public funding. Substitution effect, or embossing effect, means that public resources will replace private resources and innovative activities will remain at a stable level. The data required to perform such analyses are not available for the public in Slovakia, and the Statistical Office of the Slovak republic does not analyze this issue. The reason may be the "long-term positioning of systematic innovative policy on the periphery of interest of government and politicians" (Minerva, 2011).

The Act addressing the incentives for research and development describes and provides a possibility of applying the tax credit for activities related to research and development. Even so, private entities are usually not aware of this possibility. According to the representatives of Minerva, tax allowances for research and development are a complicated tool because they are often associated with problematic classification of eligible expenses. When it comes to venture capital, the problem is that Slovak business angels are characterized by an effort to get at least $60 \%$ of innovating private entity when they invest, which acts as a disincentive for the Inventor (innovating entity), and therefore discourages it from joining with investors. Slovakia lacks business spirit. Slovaks tend to prefer rapid earnings, which are hard to sustain in the long-term perspective. Apart from that, there is the problem with syndication in Slovakia (providing information on innovation or selling author's work), due to feeble legal certainty (Kotulič, 2006). Foreign investors in Slovakia allocated their plants focused on sale, but they do not intend to realize their research here. Insufficient infrastructure in Slovakia is one of the main reasons for the lack of interest in conducting research in Slovakia. The infrastructure would require extra investments. Despite this claim, however, it is more likely for the foreign companies to implement product innovation (Čaplánová et al., 2012). For foreign investors, costs on researchers as a type of labor force is not sufficient incentive for allocation of research and development centers in Slovakia. In addition to that, Slovakia is not perceived as a source of sufficient educational system for the needs of research and development activities and foreign direct investment is lowest within the region (Dubravská and Širá, 2014).

From the long-term perspective, there is a low quantity of scientific publications in Slovakia as well as a low number of patents that were granted by U.S. and European patent offices, and a small proportion of sophisticated products in export altogether (Baláž, 2005).

Slovakia fails when it comes to drawing on EU funds within the current programming period, too. Because of weak Slovakia's absorption capacity within the period 20072013, deadline for the Slovak Republic was extended until 2015. By the end of the 2013, only $50.92 \%$ of the money intended for Slovakia within all operational programs had been spent. Table 1 shows percentage of drawn funding by each operational program.

It is obvious that with such a weak score in Operational Program Research and Development and Operational Program Education, Slovakia cannot be a good performer in the research, development and innovation. For the Horizon 2020, government announced further measures to improve collaboration between the public and private sectors in terms of financial and organizational arrangements and human capital through 
partnerships, joint ventures and long term contracts. It plans to set up a new instrument to support young Slovak researchers and to attract top Slovak scientists working abroad to come back to the country.

Table 1 EU Fundings Drawing in Slovakia

\begin{tabular}{lc}
\hline \hline Operational Program & $\begin{array}{c}\text { Percentage of successfully } \\
\text { drawn funds }\end{array}$ \\
\hline \hline Operational Program Healthcare & $82.75 \%$ \\
Regional Operational Program & $70.35 \%$ \\
Operational Program Employment and Social Inclusion & $61.06 \%$ \\
Operational Program Technical Assistance & $54.87 \%$ \\
Operational Program Bratislava region & $52.34 \%$ \\
Operational Program Competitiveness and Economic Growth & $48.26 \%$ \\
Operational Program Informatisation of Society & $45.97 \%$ \\
Operational Program Transportation & $45.87 \%$ \\
Operational Program Research and Development & $45.20 \%$ \\
Operational Program Environment & $44.36 \%$ \\
Operational Program Education & $38.97 \%$ \\
\hline \hline
\end{tabular}

Source: Ministry of Finance of the Slovak Republic (2014)

As far as cooperation of higher education and business practice is concerned, Slovakia is characterized by the ossified educational system with minimal efforts towards changes. Despite few pioneering faculties, we find here very few study programs which are tailored to needs of the practice. The problem of incoherence of study programs and practical needs is so substantial that only one third of graduates find employment in their field of study. Moreover, from a long term perspective, firms are discontent with knowledge of new graduates and are not willing to hire them. Here the issue is to focus on IT, Engineering and Technology sectors which are emerging in Slovak economy most.

In domain of a public private partnership, only a few projects are running and mainly in the sector of road construction. Some methodological materials for use of public private partnership in healthcare, culture, sports, education and for the needs of municipalities have been elaborated, but they have not been implemented in practice.

\section{Structure of the Paper}

The aim of the paper is to answer the following questions, hypotheses:

$\mathrm{H}_{1}$ : Large companies have greater chances to succeed than other companies.

$\mathrm{H}_{2}$ : Scientific discipline of the applicant affects the likelihood of success in the grant system.

$\mathrm{H}_{3}$ : A company from the Bratislava region is more likely to succeed than a company from a different region.

The article is organized as follows: The next, third, part entitled Academic research presents theories of development and research in the field of innovation. The fourth 
section describes the analysis and databases that we worked with in logistic regression. The fifth, sixth and seventh sections present the relevant databases. The eighth, final section summarizes the results of the analysis and discussion is proposed.

\section{Academic Research}

The 1990s brought the emergence of endogenous theories of growth which established perception of technological progress as an endogenous variable. Romer (1990) and Lucas (1988) were among the main pioneers. Jones (1995) edited a model of Romero, which was based on research and development, and created a research and development growth model.

Aghion and Howitt (1992) perceived research and development as an engine of economic growth and therefore emphasized the importance of state support of private investments put into research and development. Jones and Williams (2000) developed an endogenous model into which they also incorporated the effect of knowledge spillovers, creative destruction and externalities. This model pointed out that decentralized economies invest into research and development insufficiently compared to what is socially desirable. Zeng (2000) created a model of growth with various sectors, and in this model innovations act as a means to improve quality of products and imitation, and as the process of product lines expansion. The model included both vertical and horizontal product diversities. The process of innovation and imitation in the model was set as a random phenomenon appearing in various companies. The way in which imitation and innovation occurred in the model was based on the models of Grossman and Helpman (1994), Segerstroma et al. (1990).

Grossman and Helpman set up their model in a way in which imitation and innovation could occur in the same sector, but never in the same country. On the contrary, in the model Segerstrom et al. (1990), imitation and innovation coexisted in the same country, but they could never occur in the same sector. On the basis of abovementioned, Zeng (2000) created a model in which innovation and imitation may appear in the same sector and also in the same country. In this model, economic growth is driven by interactions of innovation with imitation, but it is only determined by innovation. One of the results of Zerg suggests that providing funds for innovations may not have the same impact as taxation of imitations.

Griffith (2000) analyzed the importance of research and development for economic growth through measurement of outputs of research and development during increasing the level of research and development inputs, meaning that he measured the rate of return. He calculated that the private rate of return in the case of the companies in the U.S. was around $27 \%$. The social rate of return in the case that the results of research and development were used in the same sector in which research and development activities were carried out varies between $17 \%$ and $34 \%$. If the results of research and development are used in a sector different from the one in which the research and development activities were carried out, the social rate of return is $100 \%$.

Zachariadis (2004) applied Schumpeter's model of endogenous growth to data received from the U.S. in the period of years 1963-1988. His work shows that domestic scientific 
and research activities as well as direct foreign investments increase domestic productivity and growth of added value in the economy such as that of the U.S.

The rate of investments of companies into research and development has a positive impact on the number of patents and therefore on the technological progress that results in an increase in work productivity. Hulya (2004) analyzed data on patents from twenty OECD countries and 10\% non-OECD countries for the period of 1981-1997 which confirmed a positive relationship between GDP and innovations. The results also showed a strong positive relationship between innovations (patents) and GDP per capita in both groups of the countries.

However, only OECD countries with a large market are capable of increasing innovations through investments into research and development. Apart from that, he also concluded that his model does not describe long-term sustainable economic growth.

Pessoa (2010) developed a model of economic growth by applying research and development to production function. He used variables such as financial sources for research and development and the rate of technological growth. The data for Ireland, Sweden and the United Kingdom were used in the analysis. The results of the research showed that the relationship between economic growth and finances invested into research and development varies depending on the country. Each country has specific factors that are crucial in the model. According to Pessoa, innovation policy which only focuses on increasing spending on research and development is ineffective for increasing economic growth.

Lach (2002) analyzed the effectiveness of Israel's grant program, or more precisely, the impact of government grants into research and development on business sector. The results indicate that in the short-term period government grants replaced private investments into science and research. However, in the long-term scope, the effect of extrusion is replaced by a complementary effect and private investments into research and development are growing. This means that every extra dollar of government grants will increase investments of the private entity by 41 cents in the long-term perspective.

Duguet (2004) came with different conclusions. According to them, the state support has a neutral effect on private investments into research and development and as such it does not produce substitution or complementary effect. Zemplinerová (2010) showed that it is not necessary for innovators to be large companies, as smaller companies also have innovative potential.

Czarnitzki and Fier (2002) concentrated on direct services. They investigated the effect of the German Federal Ministry for Science and Research on innovative expenses of the business sector in the 1990s, discovering that state support has a complementary and sustainable effect on private investments, although it is decreasing. This means that a state donation of $1 \mathrm{DM}$ equals 1.37 DM of private investments. In the following period, however, it will only be 1.26 DM. Several authors, such as Czarnitzki and Fier (2002) and Heshmat and Loof (2005), reject the total effect of extrusion. On the contrary to that, other authors, such as Lach (2002), confirm the effect of extrusion in their research. 


\section{Analysis}

The next part analyses the secondary data obtained from the online database of the Agency for Research and Development (ARD) and the Agency of Operational Program Research and Development (OPRD) and data obtained on the basis of an official request. There are several provisions and acts in Slovakia that are aimed at the increase of stimulating research and development. The effective results of these efforts are barely noticeable, which is also confirmed by the constant reduction of expenses spent on research and development. In 2010, the expenses were estimated at $0.49 \%$ of GDP.

Regarding direct financial support of research and development, private entities can use grants from the Agency for Research and Development (ARD) or from the Agency of the Ministry of Education, Science, Research and Sport of the Slovak Republic for the structural funds of the European Union under the Operational Program Research and Development (OPRD).

On the basis of informative Act no. 211/2000 of the Collection of Laws on free access to information, both institutions, ARD and OPRD, are obliged to publish basic information about successful applicants for public grants. Based on this information available to public, we compiled a database of private entities, and this database was also completed by the general characteristics of the relevant organizations by using publicly available data in the Register of the Organizations of Statistical Office of the Slovak Republic. Due to data availability, we worked in this analysis with the three databases described below.

\section{Database 1}

The database 1 was compiled from data that were available on the websites of both agencies. Regarding ARD, 471 successful applications were displayed in the period of 2002-2010. In the case of OPRD, there were data for 176 successful applicants for the period of 2008-2009. The final database contains information about non-state applicants and private entities only (as we follow scientific and research activities of the private sector); due to this, the range of the final Database 1 was reduced to 478 subjects. Database 1 consisted of data such as the value of the grant, year, and the name of the company/entity.

The fact that the data were not anonymous and we had the specific names of companies allowed for completing our database with more variables from the Statistical register of organizations created by the Statistical Office of the Slovak Republic. Database 1 therefore consists of 476 subjects and 8 variables - name of the company, authorized support, discipline, legal status, region, year of establishment, size of the company (number of employees), and the type of ownership.

In the sum of EUR 170,338,337, 476 grants were awarded all together between the years 2002 and 2010. The number of approved grants regarding appeals for the ARD is 399 , which is a considerably higher number than in the case of OPRD; here, 77 grants were approved. On the contrary, the amount of grants allocated through OPRD was EUR 119, 152, 000, which exceeded the EUR 51,186,000 in the ARD twofold. 
Figure 2 describes the number of grants as well as total amount of allocated grants provided to individual regions of the Slovak Republic. In the region of Bratislava (BA), 207 grants were allocated in the total sum of EUR 57, 682,000. The smallest number of grants was listed for the region of Nitra (NR): there were only 24 of them, and they amounted to EUR 14,968 000. The region of Košice (KE) received 26 grants, however, with the total amount even lower than the region of Nitra; EUR 7,068,000. The numbers are similar for the region of Prešov (PO) (27 grants) in the total sum of EUR 12,952,000.

However, the situation is different if we perform a more detailed analysis of the redistribution of grants regarding the two agencies: The region of Bratislava is ranked on the first place. The lowest number of successful applications for grants under ARD was recorded in the region of Nitra achieving the amount of EUR 1,761,000, followed by the region of Prešov (20 grants in the sum of EUR 2,460,000) and Trnava (TT) (20 grants forming the sum of EUR 2,160,000).

Figure 2 Number and Amount of Grants by Region In ARD and OPRD

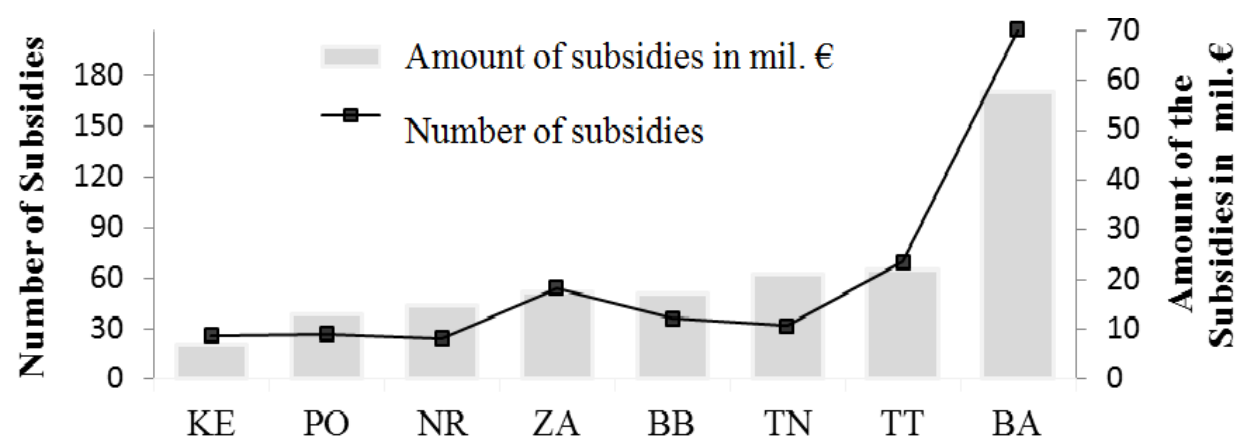

Source: Authors

In OPRD, the least successful applications were submitted in the region of Košice with 2 grants in the amount of EUR 4,238,000 (see Figure 3).

Figure 3 Number and Amount of Grants in ARD and OPRD by Region

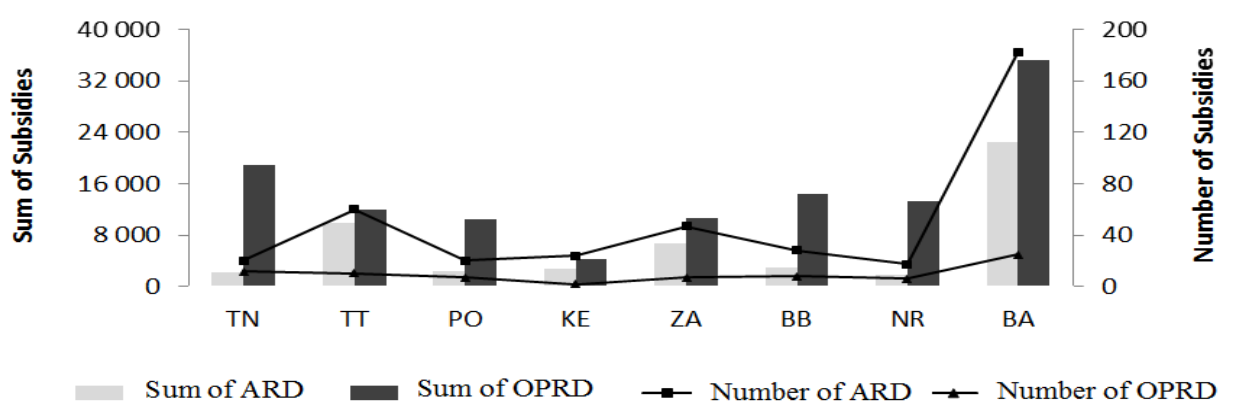

Source: Authors 
There is a gradual increase in the number of successful applications for grants shown by Figure 4, while the regions with the largest number of successful applicants are repeated every year.

Figure 4 Increase of the Number of Successful Applications by Region for the Period of 2002-2009

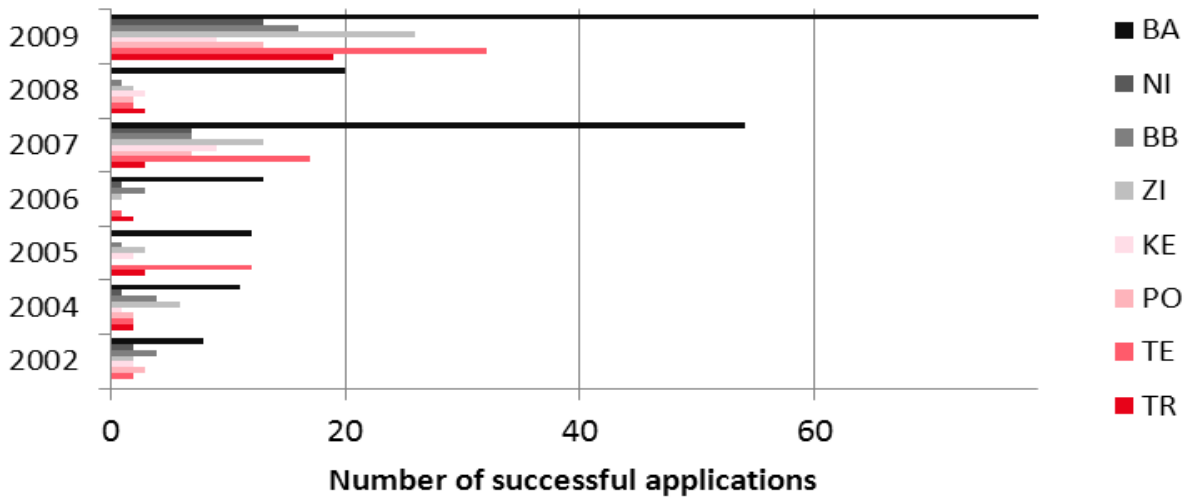

Source: Authors

Figure 5 Percentage of Applicant Success by Size Category

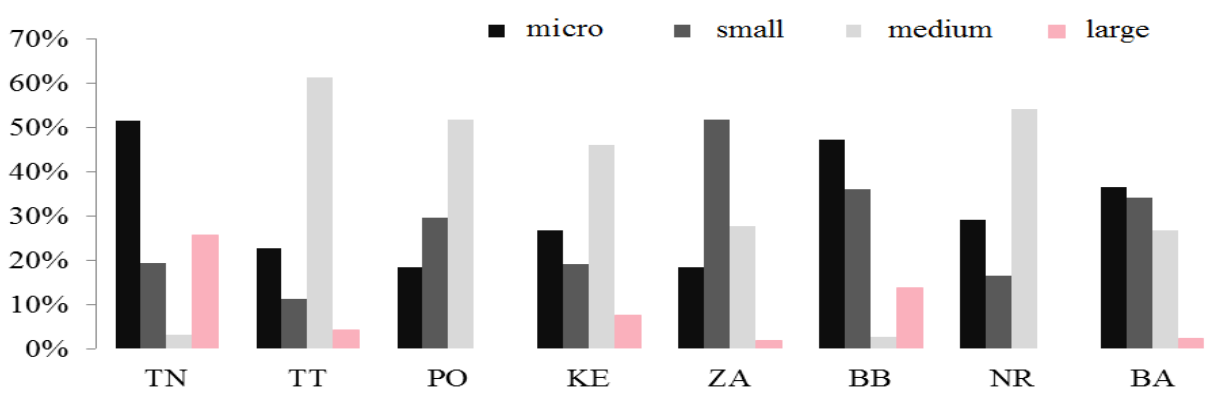

Source: Authors

Figure 5 describes companies whose applications were successful and who received a grant for science and research, distributed by regions. The companies were divided into four groups based on their size category. Figure 4 points out that the region of Trnava had the largest percentage $(25 \%)$ of successful applicants from the group of large companies (over 250 employees). It was around $5 \%$ in other regions, the only exception being the region of Banská Bystrica (BB) with 14\% of large companies. In the region of Trenčín (TN), 60\% of successful applicants were medium-sized companies (50-250 employees). The regions of Prešov and Košice showed a similar situation, where about $50 \%$ were medium-sized companies. The regions of Trnava and Banská Bystrica are 
characterized by the largest number of applicants from the group of micro businesses (under 10 employees), and small companies (under 50 employees).

\section{Database 2}

The previous part described the current situation of direct financial support in Slovakia and it also compared the distribution of grants in two agencies, ARD and OPRD. The next section focuses on practical application of dichotomous logit model to specific data about the applicants for the financial support for science and research. The model works with binary explained variables. The goal is to analyze the impact of individual characteristics of the company on obtaining grants. The logit model is one of the models with qualitative dependent variable. Qualitative variables in the model may act as dependent variables that are expressed by binary variables in the model, and they can either achieve the value of 1 if the phenomenon occurs or a value of 0 if it does not.

A majority of empirical studies about national and international grant programs is based on data about funded projects only; therefore it only takes into account successful applications that were made. However, we also present the data on unsuccessful applications in our database, and because of that we are able to express the probability of success or refusal of the application. Barajas and Huergo (2007) used the following exogenous variables in their analysis: Experience with making applications, size of the company, export, region, liquidity of the company, scientific discipline, year of application, fixed capital. Their sample consists of 3,251 claims made in Spain. Barajas and Huergo used probit model for this analysis in order to identify factors that are determining the participation of the companies in the grant program. Busom (2000) investigated the impact of the grants on research and development on the sample of 155 Spanish companies that participated in the questionnaire survey research. Variables that she used were as follows: Size of the company, export, scientific discipline, spending on research and development, age of the company, form of ownership and so forth. Herrera and Ibarra (2010) analyzed the relationship between company size and probability of obtaining grants for scientific and research activities with the use of probit and logit models. Variables that they used in the model were: Size of the company, age of the company, the percentage of foreign capital, export, region, expenses on research and development, and variables related to the market.

The studies mentioned above have led to implementation of a similar analysis in Slovakia, where the number of explanatory variables used depended on the availability of micro data. Database 2 was created for the needs of the analysis.

The database included companies that submitted an application to obtain grants from ARD and OPRD. The lists of successful applicants for specific companies can be found on the websites of both companies. Regarding the ARD, data were collected from 29 appeals, and in the case of the OPRD, there were 19 calls in the period of 2008 and 2009. In order to perform the analysis investigating how significant the relevant characteristics of each company to obtain the grant had been, it was also necessary to collect information about unsuccessful applicants. Both agencies have been formally requested to provide a list of names of unsuccessful applicants. 
Non-anonymous data were therefore essential in order to complete information on the company size, legal form, the region in which the company was located, and the type of ownership from the database of Statistical Office of Slovak Republic - Statistical register of Organizations and Urban and Municipal Statistics. However, only OPRD provided non-anonymous data. ARD provided anonymous information about the amount of grant, scientific discipline, legal form, region and the year of application related to every unsuccessful applicant (556 organizations). Withholding the data was justified by the Information Act, which requires that information about successful public applicants be made public, but does not allow providing information about unsuccessful applicants. The fact that there were numerous obstacles in obtaining the necessary data to perform the analysis as well as the lack of transparency is recognized not only by the representatives of the Slovak Organization for Research and Development Activities, but also by the representatives of Minerva.

The failure to provide non-anonymous data therefore limited the number of variables available. The final Database 2 consisted of 1169 subjects: 561 unsuccessful applications from ARD, 399 successful applications form ARD and 209 successful and unsuccessful applications from OPRD. The non-anonymous data were completed by data from the databases of the Statistical Office of Slovak Republic mentioned above.

Data file, the sample of which is available from the authors upon request, contains 7 vectors. The vector of the explained binary variable takes into account the percentage of the success, whether the ith organization received a grant, meaning whether its application made it through the selection process and was successful. Database 2 had to be modified due to missing data on the scientific discipline, the legal status and state applicants (the institutions of higher education and the Slovak Academy of Sciences were excluded), reducing the number of subjects to 827 with 7 variables.

Variables: Percentage of application success, agency, year of application, grant sum, scientific discipline and legal form of the company, the region where the company is located.

Database 2 contains 417 successful applications and 410 unsuccessful applications, out of which 344 were from the region of Bratislava, 64 from the region of Banská Bystrica, 60 from the region of Košice, 50 from the region of Nitra, 51 from the region of Prešov, 98 from the region of Trenčín, 53 from the region of Trnava, and 107 from the region of Žilina. The number of applications by the appeal for grant announcement is shown in Table 2.

Table 2 Summary of Success and the Sum of Required Grant from ARD and OPRD

\begin{tabular}{|c|c|c|c|c|c|c|c|c|}
\hline Success & $\mathbf{B A}$ & BB & KE & NR & PO & $\mathbf{T N}$ & TT & $\mathbf{Z A}$ \\
\hline 0 & 182 & 31 & 36 & 26 & 27 & 35 & 25 & 55 \\
\hline 1 & 162 & 33 & 24 & 24 & 24 & 63 & 28 & 52 \\
\hline \multicolumn{4}{|c|}{ Amount of required subsidy (mil. $€$ ) } & up to 0.5 & $0.5-1$ & $1-1.5$ & $1.5-2$ & over 2 \\
\hline \multicolumn{4}{|c|}{ Number of applications } & 571 & 35 & 35 & 34 & 152 \\
\hline
\end{tabular}

Source: Authors 
The regressive model specifies the relationship between the percentage of success of the applications and the characteristics of the applicant. The explanatory variable is a binary variable, meaning that the chosen technique of data analysis is a logistic regression. There are 6 other vectors of explanatory variables entering into the logistic regressive model: two numerical (year, grant) and four categorical explanatory variables. MODEL 1 has the following form:

$$
\begin{aligned}
\operatorname{SUCCESS}_{i}=\beta_{0}+\beta_{1} \text { AGENCY }_{i}+ & \beta_{2} \text { YEAR }_{i}+\beta_{3} \text { GRANT }_{i}+\beta_{4} \text { DISCIPLINE }_{i}+\beta_{5} \text { FORM }_{i} \\
& +\beta_{6} \text { REGION }_{i}+u_{i}
\end{aligned}
$$

where

$u_{i}$

$\operatorname{SUCCESS}_{i}$

$A G E N C Y_{i}$

$Y E A R_{i}$

$G R A N T_{i}$

DISCIPLINE

FORM $_{i}$ is a random component which describes the influence of the factors that are not displayed

is a binary variable which describes the success of the applications within the agencies

0 , if the application of the private entity was not successful (it did not pass selection process),

1 , if application was successful

is a binary variable for one of the two agencies providing grants

0 , if the request was made within OPRD,

1 , if the request was made within the ARD.

stands for the year of announcement of appeals based on which applications are submitted for receiving grants. The YEAR variable can achieve values from 1 to 9 in logistic regression, where 1 means the year 2002, 2 is the year 2004, 3 is the year 2005 up to number 9, which is 2011. Data for 2003 were not available.

is the amount of the required grant; it is divided into 5 intervals.

,$a^{\prime \prime}$ if the amount of the required grant does not exceed EUR 500,000 ,

,$b$ " if the amount varies between EUR 0.5 million and 1 million,

„,c" is from EUR 1 million to 1.5 million,

,$d^{\prime \prime}$ is from EUR 1.5 million do 2 million,

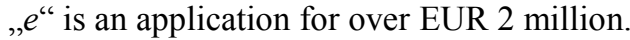

is a scientific discipline in which the applying company operates.

„art" are arts, ,med“" medical sciences, ,agr" are agricultural sciences, ,pop" is popularization, ,nat" means natural science, ,soc" are social sciences, ,tech" are technical sciences.

is the legal form of the applicant. The division is based on the classification of the Statistical Office of the Slovak Republic and its encoding.

,jsc" - code 121 joint-stock company

„,company“- this group contains the codes 109 ( Enterpreneur - natural person - not registered in the commercial register - a company as well as a freelancer), 101 (Enterpreneur - natural person - not registered in 
commercial register), 102 (Enterprise - natural person - registered in commercial register),

„llc" - code 112, Limited liability company

,alp“ - code 751, Association of legal persons

„aso“ - code 701, Association (union, society, club, etc.)

$R_{E G I O N_{i}} \quad$ is the region in which the institution applying for grant is located.

„BA" is the region of Bratislava, „TT" is the region of Trnava, „TN" is the region of Trenčín, "NR“ is the region of Nitra, , $Z A^{*}$ is the region of Žilina, „BB“ is the region of Banská Bystrica, „PO“ is the region of Prešov and , $K E^{،}$ is the region of Košice.

Table 3 The Estimated Regressive Coefficients of MODEL 1

\begin{tabular}{|c|c|c|c|c|c|}
\hline Logit & Estimate & Std. Error & z value & $\operatorname{Pr}(>|z|)$ & \\
\hline (Intercept) & -9.62798 & 3971.85039 & -0.002 & 0.9981 & \\
\hline AGENCYoprd & 4.92545 & 0.56664 & 8.692 & $<2 \mathrm{e}-16$ & $* * *$ \\
\hline$Y E A R$ & -0.57848 & 0.06809 & -8.496 & $<2 \mathrm{e}-16$ & $* * *$ \\
\hline GRANTa & -3.29082 & 0.67515 & -7.223 & $4.00 \mathrm{e}-07$ & $* * *$ \\
\hline$G R A N T b$ & -4.02528 & 0.66148 & -6.085 & $1.16 \mathrm{e}-09$ & $* * *$ \\
\hline GRANTc & -3.80956 & 0.68215 & -5.585 & $2.34 \mathrm{e}-08$ & $* * *$ \\
\hline GRANTd & -4.10481 & 0.65951 & -6.224 & $4.84 \mathrm{e}-10$ & $* * *$ \\
\hline GRANTe & -4.73283 & 0.51027 & -9.275 & $<2 \mathrm{e}-16$ & $* * *$ \\
\hline DISCIPLINEmed & 13.10146 & 3971.85039 & 0.003 & 0.9974 & \\
\hline DISCIPLINEagr & 13.18298 & 3971.85038 & 0.003 & 0.9974 & \\
\hline DISCIPLINEpop & 12.27138 & 3971.85038 & 0.003 & 0.9975 & \\
\hline DISCIPLINEnat & 13.44663 & 3971.85037 & 0.003 & 0.9973 & \\
\hline DISCIPLINESOc & -2.65696 & 3871.91180 & -0.001 & 0.9995 & \\
\hline DISCIPLINEtech & 13.17828 & 3971.85036 & 0.003 & 0.9974 & \\
\hline FORMcompany & -1.84805 & 0.85328 & -2.166 & 0.0303 & $*$ \\
\hline FORMllc & 0.20677 & 0.19621 & 1.054 & 0.2920 & \\
\hline FORMalp & 31.08643 & 1262.53341 & 0.025 & 0.9804 & \\
\hline FORMaso & 0.98478 & 0.59426 & 1.657 & 0.0975 & . \\
\hline REGION BB & -0.04287 & 0.35301 & -0.121 & 0.9033 & \\
\hline REGION KE & -0.15752 & 0.35100 & -0.449 & 0.6536 & \\
\hline REGION NR & 0.33331 & 0.38065 & 0.876 & 0.3812 & \\
\hline REGION BA & 0.17059 & 0.34883 & 0.516 & 0.51631 & \\
\hline REGION PO & -0.17728 & 0.37398 & -0.474 & 0.6355 & \\
\hline REGION TN & 0.71995 & 0.30436 & 2.365 & 0.0180 & $*$ \\
\hline REGION TT & 0.42579 & 0.38873 & 1.095 & 0.2734 & \\
\hline REGION ZA & 0.09275 & 0.29007 & 0.320 & 0.7492 & \\
\hline
\end{tabular}

We also decided to perform the test of statistical significance of the relevant variables due to the multivalent results. The results show that the variable "REGION" is not statistically significant, but "LEGAL FORM" is significant (see Table 4).

Source: Authors 
Table 3 shows regressive coefficients (Estimate), standard errors of these coefficients (Std. error), and tests of significance of relevant regressive coefficients $(\operatorname{Pr}(>|z|))$. During estimation of a regressive model with the logit method for the dependent variable "SUCCESS", statistically significant variables "AGENCY", "YEAR", "GRANT" were obtained at the significance level of less than 0.01 and variables "FORM", and "RE$G I O N "$ at the significance level of 0.05 . The results of logit are displayed in Table 2. It is apparent from the output that the variable "DISCIPLINE" is an insignificant variable, and in the case of the variables "REGION" and "FORM", the result is not clear, since one value of the factors is significant and the others are not.

In order to choose the suitable model, we were looking for the model with the smallest value of Akaike's information criterion (AIC), and we did it by exploring models with all the possible combinations of variables, using one of three strategies. The FORWARD strategy (forward selection) selects variables according to their significance. The BACKWARD strategy (backward) is based on a complex model in which the variables gradually fall out based on their significance. The third strategy is the combination of the two strategies mentioned above (Halekoh, 2007). AIC indicates that the explanatory variables are statistically important, with the exception of the variables "REGION" and "DICSIPLINE".

Table 4 Test of Statistical Significance of logit MODEL 1

\begin{tabular}{ccccccc}
\hline & Df & Deviance & AIC & LRT & Pr(Chi) & \\
\hline (Intercept) & & 759.27 & 807.27 & & & \\
AGENCY & 1 & 885.02 & 931.02 & 125.757 & $<2.2 \mathrm{e}-16$ & $* * *$ \\
YEAR & 1 & 858.58 & 904.58 & 99.316 & $<2.2 \mathrm{e}-16$ & $* * *$ \\
GRANT & 4 & 1002.46 & 1042.46 & 243.194 & $<2.2 \mathrm{e}-16$ & $* * *$ \\
DISCIPLINE & 6 & 769.2 & 805.2 & 9.93 & 0.1276 & \\
FORM & 4 & 804.34 & 844.34 & 45.077 & $3.83 \mathrm{E}-09$ & $* * *$ \\
REGION & 7 & 768.07 & 802.07 & 8.805 & 0.267 & \\
\hline
\end{tabular}

Source: Authors

On the basis of the analysis above, a new model was created in which we excluded the variables "REGION" and "DISCIPLINE". The estimation of regressive parameters of Model 2 is shown in Table 5. The final shape of the model is as follows:

$$
\operatorname{SUCCESS}_{i}=\beta_{0}+\beta_{1} A G E N C Y_{i}+\beta_{2} \text { YEAR }_{i}+\beta_{3} G R A N T_{i}+\beta_{4} F O R M_{i}+u_{i}
$$

Once we know the estimates of regressive coefficients $\beta$, it enables us to test the null hypothesis using two-sided confidence intervals with the use of a method based on maximum likelihood (the so-called likelihood method) (King, 2009).

If the relevant interval contains 1 , it means that the parameter is not significant at the selected level of importance. Table 6 offers a summary of the confidence intervals for specific parameters where the following can be considered as statistically significant at the significance level of 5\%: The year of the appeal, the amount of required grant, agency and the legal form of "entrepreneur - natural person". 
Table 5 The Estimated Regressive Coefficients of MODEL 2

\begin{tabular}{ccccccc}
\hline Logit & Estimate & Std. Error & z value & & $\operatorname{Pr}(>|\mathbf{z}|)$ & \\
\cline { 6 - 7 } \cline { 5 - 6 } (Intercept) & 3.67460 & & 0.41514 & 8.851 & $<2 \mathrm{e}-16$ & $* * *$ \\
\hline AGENCYoprd & 4.94936 & 0.55188 & 8.968 & $<2 \mathrm{e}-16$ & $* * *$ \\
\hline YEAR & -0.58157 & 0.06644 & -8.754 & $<2 \mathrm{e}-16$ & $* * *$ \\
\hline GRANTa & -3.77821 & 0.66129 & -5.212 & $1.92 \mathrm{e}-08$ & $* * *$ \\
GRANTb & -3.93491 & 0.66853 & -5.886 & $3.96 \mathrm{e}-09$ & $* * *$ \\
GRANTc & -3.68110 & 0.64710 & -5.689 & $1.28 \mathrm{e}-08$ & $* * *$ \\
GRANTd & -4.08801 & 0.64830 & -6.306 & $2.87 \mathrm{e}-10$ & $* * *$ \\
GRANTe & -4.70248 & 0.50561 & -9.301 & $<2 \mathrm{e}-16$ & $* * *$ \\
\hline FORMcompany & -1.79515 & 0.84509 & -2.124 & 0.0337 & $*$ \\
FORMllc & 0.17531 & 0.18444 & 0.951 & 0.3419 & \\
FORMalp & 16.96835 & 618.77376 & 0.027 & 0.9781 & \\
FORMaso & 0.35140 & 0.47380 & 0.742 & 0.4583 & \\
\hline SOUTC: Authors & & & &
\end{tabular}

Source: Authors

Table 6 Two-sided Confidence Intervals

\begin{tabular}{ccc}
\hline Logit & $\mathbf{2 . 5 0 \%}$ & $\mathbf{9 7 . 5 0 \%}$ \\
\hline (Intercept) & 2.8932855 & 4.5230114 \\
\hline AGENCYoprd & 3.9434722 & 6.1388389 \\
\hline YEAR & -0.7166756 & -0.4559109 \\
\hline GRANTa & -5.2591441 & -3.2879401 \\
GRANTb & -5.3504929 & -2.7154287 \\
GRANTc & -5.0337169 & -2.4721696 \\
GRANTd & -5.4399017 & -2.8728179 \\
GRANTe & -5.8233695 & -3.8083421 \\
\hline FORMcompany & -3.6897806 & -0.3084294 \\
FORMllc & -0.1850136 & 0.5387226 \\
FORMalp & -12.2584471 & 205.5636165 \\
FORMaso & -0.5813697 & 1.2910248 \\
\hline
\end{tabular}

Source: Authors

The interpretation in the case of these models is not simple since we are not able to directly interpret the obtained results as in the case of usual regressive analysis. It is necessary for regressive coefficients to be at first transformed by exponentiation which gives us probability ratios.

A chance that the applying project of the company will be successful is higher for a project submitted through OPRD (about 141.08 times), than for a project submitted through the ARD. In regard to the year of opening of appeals for applications, the chance of success is lower with each passing year. It means that the probability of success in 2005 was higher than the probability of success in 2010. In addition to that, we see that the highest chance of success is if the application requires the amount of up to five hundred thousand euros (grant , $a^{\text {" }}$ ) in comparison to applications requiring a different range. After analyzing the results, it appears that the probability of success decreases if budgets are higher than half a million. As far as the legal form is concerned, 
results show that individuals registered in the commercial register, individuals not registered and doing business as freelancers are 1.66 times more likely to be successful than applications of joint stock companies.

Table 7 MODEL 2 - Logit

\begin{tabular}{cccccc}
\hline (Intercept) & AGENCYoprd & YEAR & GRANTa & GRANTb & GRANTc \\
39.4329 & 141.084 & 0.5590206 & 0.0947922 & 0.01954743 & 0.0251952 \\
\hline GRRANTd & GRANTe & FORMcompany & FORMIlc & FORMalp & FORMaso \\
0.016773 & 0.00907 & 0.166103 & 1.19162 & $2.340 \mathrm{e}+07$ & 1.421061 \\
\hline Source: Authors & & & & &
\end{tabular}

In order to better understand the results related to the size of the required grants, we provided a descriptive Table 8. Most applications are with the required grant up to EUR 500,000 . If we take a look at the situation of the success of the application regarding the amount of the grant, it points to the high failure rate of $88 \%$ for "EUR 2 million and more", 74\% for "EUR 0.5-1 million".

Table 8 Success Rate Depending on the Amount of the Grant

\begin{tabular}{c|cccccc}
\hline \hline $\begin{array}{c}\text { \% to the total sum in } \\
\text { terms of success }\end{array}$ & $\begin{array}{c}\text { up to EUR } \\
\mathbf{0 . 5} \text { mil. } \boldsymbol{€}\end{array}$ & $\begin{array}{c}\text { EUR 0.5- } \\
\mathbf{1} \text { mil. }\end{array}$ & $\begin{array}{c}\text { EUR 1-1.5 } \\
\text { mil. }\end{array}$ & $\begin{array}{c}\text { EUR 1.5- } \\
\mathbf{2} \text { mil. }\end{array}$ & $\begin{array}{c}\text { over EUR } \\
\mathbf{2} \text { mil. }\end{array}$ & $\begin{array}{c}\text { Total } \\
\text { sum }\end{array}$ \\
\hline 0 & $54 \%$ & $6 \%$ & $4 \%$ & $4 \%$ & $32 \%$ & 417 \\
1 & $85 \%$ & $2 \%$ & $5 \%$ & $4 \%$ & $4 \%$ & 410 \\
\hline $\begin{array}{c}\text { \% to the total sum in } \\
\text { terms of category }\end{array}$ & $\begin{array}{c}\text { up to EUR } \\
\mathbf{0 , 5} \text { mil. }\end{array}$ & $\begin{array}{c}\text { EUR } \mathbf{0 , 5}- \\
\mathbf{1} \text { mil. }\end{array}$ & $\begin{array}{c}\text { EUR 1-1,5 } \\
\text { mil. } \\
\text { mil. } €\end{array}$ & $\begin{array}{c}\text { EUR 1,5- } \\
\mathbf{2} \text { mil. }\end{array}$ & $\begin{array}{c}\text { over EUR } \\
\mathbf{2} \text { mil. }\end{array}$ & \\
\hline 0 & $39 \%$ & $74 \%$ & $46 \%$ & $50 \%$ & $88 \%$ & \\
1 & $61 \%$ & $26 \%$ & $54 \%$ & $50 \%$ & $12 \%$ & \\
\hline Total summary & 571 & 35 & 35 & 34 & 152 & \\
\hline
\end{tabular}

Source: Authors

MODEL 2 was also tested for multicolinearity. Multicolinearity means a mutual correlation of explanatory variables. In order to test dependence, the variance influence factor (VIF) was used. VIF indicates strong colinearity if the value is greater than 10 . We reject the issue of multicolinearity in our case.

In order to test the importance of Model 2, McFadden pseudo coefficient of determination was used. Low values of McFadden coefficient would prove the low explanatory value of the model, meaning that studied relationships are actually more complicated than in the model. The optimal level of the coefficient is considered to be 0.2 to 0.4 . The values of McFadden coefficient of tested Model 2 show the suitability of Model 2. We therefore reject Hypothesis $\mathrm{H}_{0}$ : The model as a whole is not significant. 
Table 9 Multicolinearity Test

\begin{tabular}{cccc}
\hline & GVIF & Df & GVIF^(1/(2*Df)) $^{*}$ \\
\hline AGENCY & 5.812598 & 1 & 2.410933 \\
YEAR & 1.210982 & 1 & 1.100446 \\
GRANT & 5.487323 & 4 & 1.237143 \\
FORM & 1.072271 & 4 & 1.008760 \\
\hline
\end{tabular}

Source: Authors

Table 10 McFadden Test of Significance

\begin{tabular}{cccccc}
\hline Ilh & IlhNull & G2 & McFadden & r2ML & r2CU \\
\hline$-389,9292761$ & $-573,2030928$ & 366,5476334 & 0.3197363 & 0.3580377 & 0.4773950 \\
\hline
\end{tabular}

Source: Authors

We performed again the test of statistical significance of the new MODEL 2 and relevant considered variables. The output shows that all the variables are statistically significant.

Table 11 Test of MODEL 2 Statistical Significance

\begin{tabular}{ccccccc}
\hline & Df & Deviance & AIC & LRT & $\operatorname{Pr}$ (Chi) & \\
\hline AGENCY & 1 & 920.72 & 940.72 & 139.475 & $2.2 \mathrm{e}-16$ & $* * *$ \\
YEAR & 1 & 886.60 & 906.60 & 105.356 & $2.2 \mathrm{e}-16$ & $* * *$ \\
GRANT & 4 & 1025.27 & 1039.27 & 244.024 & $2.2 \mathrm{e}-16$ & $* * *$ \\
FORM & 4 & 818.63 & 832.63 & 37.384 & $1.501 \mathrm{e}-07$ & $* * *$ \\
\hline
\end{tabular}

Source: Authors

\section{Database 3}

The previous section presented an analysis of data which were obtained from both agencies. However, only one of them, Agency of the Ministry of Education, Science, Research and Sport of the Slovak Republic for the Structural Funds of EU, provided non-anonymous data. This chapter will closely describe the current situation in allocating grants in regard of the Agency of the Ministry of Education, Science, Research and Sport of the Slovak Republic. Database 3 was created in order to meet the needs of the analysis.

In order to create the necessary database, requests were sent to both ARD and OPRD agencies to provide non-anonymous data (company name and the size of the requested grant) of all the companies that submitted an application, regardless of whether they had passed the selection process or not. The ARD provided a list of unsuccessful applicants; it was, however, anonymous. The reason was the Information Act 211/2000 of the Collection of Laws. Only the Agency of the Ministry of Education, Science, Research and 
Sport of the Slovak Republic for the Structural Funds of EU provided the company names requested. Non-anonymous data about applicants were essential for completing the specific characteristics of the applicants from the database of the Statistical Office of the Slovak Republic - Statistical Register of Organizations and Urban and Municipal Statistics. Due to the limitations mentioned above, the created database therefore consists of 209 claims and 9 variables.

Variables are as follows: Name of the company, year of the appeal for submitting applications, requested grant sum, approved grant sum, scientific discipline, legal form of the company, founding year of the company, size of the company (number of employees), and type of ownership.

Most applications submitted by the Operational Program Research and Development are in the range of more than EUR 1.5 million (127 out of 209 applications). The success rate (number of successful requests/total applications) and the rate of funding (amount of approved grant/amount of requested grant) are not homogeneous. The highest success rate $(63.2 \%)$ of the applications submitted in the case of requesting grant ranges from EUR $1,500,000$ to $2,000,000$, and the highest funding rate of $99 \%$ in the required amount is in the case of the smallest projects up to half a million $€$, see Table 12.

Table 12 Rate of Success and Funding Regarding Projects of the Agency of the Ministry of Education, Science, Research and Sport of the Slovak Republic for the Structural Funds of the EU

\begin{tabular}{cccc}
\hline Amount of grant & $\begin{array}{c}\text { Number of } \\
\text { applications }\end{array}$ & Success rate & Funding rate \\
\hline \hline Up to EUR 0.5 mil. & 14 & $27.3 \%$ & $99.1 \%$ \\
EUR 0.5-1mil. & 18 & $50.0 \%$ & $80.3 \%$ \\
EUR 1-1.5mil. & 50 & $47.1 \%$ & $96.0 \%$ \\
EUR 1.5-2mil. & 62 & $63.2 \%$ & $91.4 \%$ \\
Over EUR 2 mil. & 65 & $41.3 \%$ & $97.3 \%$ \\
\hline
\end{tabular}

Source: Authors

The success rate of the applications submitted depending on the region in which the company is located is displayed in Table 13. One can observe a significant difference between the regions of Bratislava (BA), Banská Bystrica (BB) and Nitra (NR), where about $36 \%$ of all applications were successful, and the region of Košice (KE), with a low, 25\% success rate. The regions of Prešov PO, Trenčín (TT) and Trnava (TN) reached success level of $28 \%$ and $33 \%$ in the region of Žilina (ZA) (see Figure 5 and Table 13).

If we observe the years 2009 and 2010 in particular, it is clear that the overall success rate decreased from $41.11 \%$ to $25.64 \%$. In the region of Bratislava, the success rates decreased from $53.7 \%$ to $23.81 \%$, while the number of applications increased by $50 \%$. In the regions of Žilina, Nitra and Trenčín, success rate increased by about $5 \%$, while the region of Žilina also recorded an increase in the number of submitted applications 
by $70 \%$; in the region of Trnava, it increased by $25 \%$, the number only decreased in the region of Nitra by $16.7 \%$. The most successful application projects were submitted in 2009 in the region of Bratislava and in 2010 in the region of Nitra (see Figure 6).

Table 13 Success Rate of Submitted Applications Depending on Region

\begin{tabular}{cccccc}
\hline & $\begin{array}{c}\text { Number of } \\
\text { companies }\end{array}$ & $\begin{array}{c}\text { Number of } \\
\text { applications }\end{array}$ & $\begin{array}{c}\text { Number of suc- } \\
\text { cessful applica- } \\
\text { tions }\end{array}$ & $\begin{array}{c}\text { Average number } \\
\text { of request per } \\
\text { applicant }\end{array}$ & Success rate \\
\hline BA & 52 & 70 & 25 & 1.346154 & $35.71 \%$ \\
TT & 13 & 19 & 6 & 1.461538 & $31.58 \%$ \\
TN & 22 & 25 & 7 & 1.136364 & $28.00 \%$ \\
NR & 7 & 11 & 4 & 1.571429 & $36.36 \%$ \\
ZA & 20 & 27 & 9 & 1.35 & $33.33 \%$ \\
BB & 17 & 19 & 7 & 1.117647 & $36.84 \%$ \\
PO & 16 & 21 & 6 & 1.3125 & $28.57 \%$ \\
KE & 11 & 16 & 4 & 1.454545 & $25.00 \%$ \\
\hline Sum & 158 & 208 & 68 & 1.316456 & $32.69 \%$ \\
\hline
\end{tabular}

Source: Authors

Figure 6 Success Rate of Projects Depending on the Amount of the Requested Grant and Region
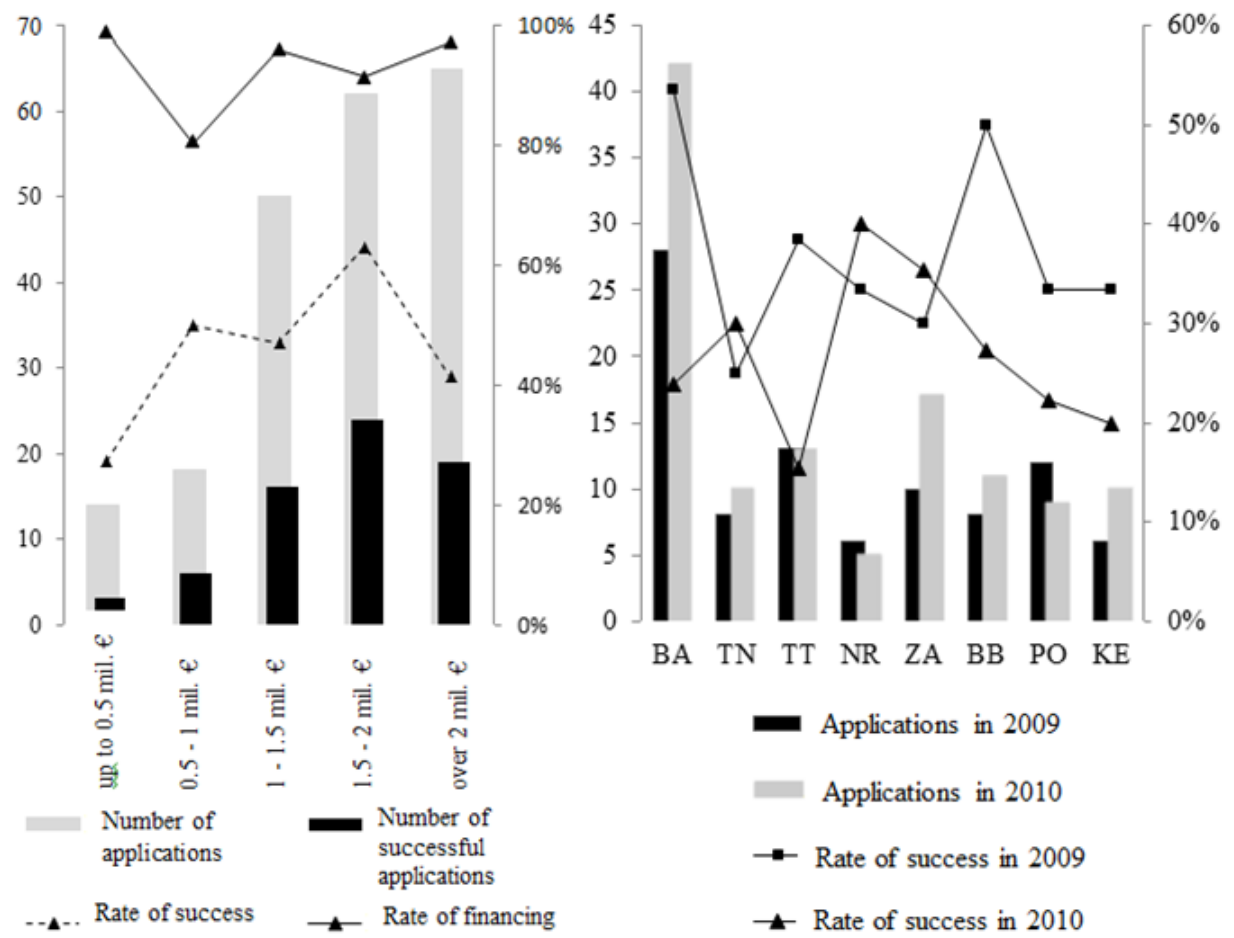

BA TN TT NR ZA BB PO KE

Applications in 2009

Applications in 2010

- Rate of success in 2009

— Rate of success in 2010

Source: Authors 
The analysis of applicants by age or founding date respectively shows that $59 \%$ of successful applicants operate in the market for more than 16 years. Regarding the unsuccessful applicants, 34\% of them exist in the market for more than 16 years and $25 \%$ operate in the market from 5 to 9 years.

In the same way as in the previous chapter, the following data were subjected to the logit analysis. The state-owned entities have been excluded from the database. Model 3 has the following form:

$$
S U C C E S S_{i}=\beta_{0}+\beta_{1} G R A N T_{i}+\beta_{2} F O R M i+\beta_{3} R E G I O N i+\beta_{4} S I Z E i+\beta_{5} A G E_{5}+u_{i}
$$

Explanatory variables are scaled in the same way as in the previous models, but the explanatory variable size of the company was added with the following scaling:

$S I Z E_{i} \quad$ is the size of the company applying for a grant. Companies were divided according to directives of the European Union, where the "micro" business has 0-9 employees,

"small" company 10-49 employees,

"medium" company has 50-249 employees and

"large" company has 250 or more employees.

Table 14 Estimated Regressive Coefficients in MODEL 3

\begin{tabular}{ccccc}
\hline Logit & Estimate & Std. Error & z value & Pr $(>|\mathbf{z}|)$ \\
\hline (Intercept) & $-1.475 \mathrm{e}+01$ & $8.827 \mathrm{e}+02$ & -0.017 & 0.9867 \\
\hline GRANT & $-3.363 \mathrm{e}-08$ & $2.041 \mathrm{e}-07$ & -0.165 & 0.8691 \\
\hline FORMcompany & $-6.978 \mathrm{e}-01$ & $1.264 \mathrm{e}+00$ & -0.552 & 0.5808 \\
\hline REGION BB & $4.617 \mathrm{e}-02$ & $5.979 \mathrm{e}-01$ & 0.077 & 0.9385 \\
REGION KE & $-6.602 \mathrm{e}-01$ & $6.513 \mathrm{e}-01$ & -1.014 & 0.3107 \\
REGION NR & $2.932 \mathrm{e}-01$ & $7.386 \mathrm{e}-01$ & 0.397 & 0.6914 \\
REGION BA & $1.276 \mathrm{e}-01$ & $8.827 \mathrm{e}+01$ & 0.014 & 0.9885 \\
REGION PO & $-2.734 \mathrm{e}-01$ & $5.615 \mathrm{e}-01$ & -0.487 & 0.6263 \\
REGION TN & $-4.087 \mathrm{e}-01$ & $5.439 \mathrm{e}-01$ & -0.751 & 0.4524 \\
REGION TT & $-1.255 \mathrm{e}-01$ & $5.925 \mathrm{e}-01$ & -0.212 & 0.8323 \\
REGION ZA & $3.216 \mathrm{e}-02$ & $5.137 \mathrm{e}-01$ & 0.063 & 0.9501 \\
\hline AGE & $8.251 \mathrm{e}-02$ & $3.246 \mathrm{e}-02$ & 2.542 & $0.0110 *$ \\
\hline SIZEmicro & $1.337 \mathrm{e}+01$ & $8.827 \mathrm{e}+02$ & 0.015 & 0.9879 \\
SIZEsmall & $1.284 \mathrm{e}+01$ & $8.827 \mathrm{e}+02$ & 0.015 & 0.9884 \\
SIZEmedium & $1.311 \mathrm{e}+01$ & $8.827 \mathrm{e}+02$ & 0.015 & 0.9882 \\
SIZElarge & $1.355 \mathrm{e}+01$ & $8.827 \mathrm{e}+02$ & 0.015 & 0.9878 \\
\hline
\end{tabular}

Source: Authors 
Table 14 displays that age of the company is the only statistically important variable. A test of significance of the overall variable was carried out, which only confirmed that the only statistically significant variable is the " $A G E$ " of the company.

The increase of the age of the company goes hand in hand with the increase of the chance of obtaining grants. McFadden test of the significance of the model indicates a low explanatory value of Model 3 (McFadden $=0.05345812$ ). Due to this fact, additional tests have not been performed. The reason for obtaining these results is most likely a small sample of subjects.

A similar analysis with statistically significant regressive coefficients would be possible to perform only after being provided with the data about unsuccessful applicants from the Agency for Research and Development.

\section{Conclusion}

The article analyses the support system of science and research in Slovakia with focus on private entities. An existence of positive externalities that bring greater benefit to society than to the private entity is the argument for the inevitability of state supporting research and development. However, private entities are mainly interested in the achievement of their profits, and welfare of society is therefore secondary. Due to this fact, it is necessary for the government to encourage and motivate private entities to invest into scientific research activities that are beneficial to society. This study was chosen because of absence of scientific studies comparing and analyzing incentives of the state support in the field of science and research in Slovakia. Apart from that, the sector of science and research is the main goal of the Strategy of the European Union 2020, which indicates its importance, recency and the need to provide clear information.

Only information about the low investments into science and research in Slovakia and about innovative activity is available at the moment, which is also shown by the position of Slovakia in the Summary innovative index. Besides what has been mentioned above, individual grant agencies provide an overview of the allocation of financial resources, but it is not possible to find any study evaluating and comparing the success rate regarding granting agencies. In order to do so, relevant secondary data were collected and subsequently, three databases were created in order to perform a logit analysis. Afterwards, logit analysis investigated which characteristics of a private entity are important for the application for financial support to be successful. The working hypotheses were as follows:

$\mathrm{H}_{1}$ : Large companies have greater chances to succeed than other companies.

$\mathrm{H}_{2}$ : Scientific discipline of the applicant affects the likelihood of success in the grant system.

$\mathrm{H}_{3}$ : A company from the Bratislava region is more likely to succeed than a company from a different region.

The abovementioned hypotheses were tested with logit and probit analyses. Due to similarity of results, the article only presents the results of logit analysis. The results of probit analysis will be provided by the authors upon request. This type of analysis has 
never been performed before in Slovakia (to the best knowledge of the authors). The analysis was based on studies performed in different countries, which are briefly presented in the second part of the article "Academic research".

The significance of the effect of company characteristics on its success rate in receiving a direct support, a grant, was investigated by the logit analysis. There was a statistical significance demonstrated in the variables of a company's time of operation in the market, amount of the required grant, legal form of the company and the agency in which the application for grant was submitted. The variables of discipline and the region of the company have not been confirmed as significant in relation to the success rate of the company.

As far as the abovementioned facts are concerned, we can conclude that applicants with legal form Ltd. (limited liability company) have a higher chance of receiving grant than other legal forms. The highest chance of success has a request for a grant of up to EUR 500,000 . According to the results of analysis, request filed under the Operational Program Research and Development is 141 times more likely to succeed than applications filed under the Agency for Research and Development. An important discovery is the fact that the chance to obtain the grant decreases with each passing year.

The lack of data related to finances invested into science, research and innovative activities of companies in Slovakia does not offer a comprehensive view of the current situation in the Slovak economy. The data that are available at the moment do not allow observing the effectiveness of the grants provided by public sources. Although government agencies perform partial surveys and questioning grant applicants, these surveys are not uniform and do not allow comparison or analysis of the real state of the issue of state grants provided for research and development in the long term perspective.

It would be desirable for economic practice to establish a uniform questionnaire which would provide identical data on investments into research, development and innovative activities of companies about the grants received, the successful or unsuccessful requests of companies that applied for state support in various forms.

Authors see specific suggestions for data collection study in CIS3 (Community Innovation Surveys, 2001). The use of this method of data collection would allow for monitoring the innovative level of development of relevant companies as well as tracking the level of global innovation in Slovakia and the current situation of the innovative potential of Slovak companies.

\section{References}

AGHION, P.; HOWITT, P. (1992). A model of growth through creative destruction. Econometrica. 1992, Vol. 60, No. 2, pp. 323-351.

ARROW, K. (1962). Economic Welfare and the Allocation of Resources for Invention. In: The Rate and Direction of Inventive Activity: Economic and Social Factors. National Bureau of Economic Research, Inc. 1962. ISBN: 0-87014-304-2.

BALÁŽ, V. (2005). Politika Inovácií V Slovenskej Republike. Politická ekonomie. 2005, Vol. 53, No. 4, pp. 513-526. 
BARAJAS, A.; HUERGO, E. (2010). International R\&D cooperation within EU framework programe: the case of spanish firms. In Economics of Innovation and new technology - Special Issue on the Role and Dynamics of Corporate R\&D. 2010, Vol. 19, No. 1, pp. 87-111.

BUSOM, I. (2000). Empirical evaluation of the effects of R\&D subsidies. In Economics of innovation and new technology. 2000. Vol. 9, No.2, pp. 111-148.

CZARNITZKI, D.; FIER, A. (2002). Do innovation subsidies crowd out private investment? Evidence from German service sector. Applied Economics Quarterly. 2002, Vol. 48, No. 1, pp. 1-25.

ČAPLÁNOVÁ, A.; SIVÁK, R.; HUDSON, J. (2012). Vplyv priamych zahraničných investícií na inovačnú činnost' firiem. Politická ekonomie. 2012, Vol 60, No. 6, pp. 764 779 .

DUBRAVSKÁ, M.; Širá, E. (2014). Analýza vybraných ukazovatel’ov rozvoja inovatívneho prostredia $\mathrm{v}$ SR a ČR. In XVII. mezinárodní kolokvium o regionálních vědách. Sborník př́spěvků. Brno: Masarykova univerzita, (ISBN 978-80-210-6840-7, p. 194-200)

DUGUET, E. (2004). Are subsidies a substitute or a complement to privately funded R\&D? Evidence from France using propensity score methods for non-experimental data. Revue Economie Politique. 2004, Vol. 114. No. 2 pp. 263-292.

EUROPEAN COMISSION. (2011). Innovation Union Scoreboard 2011. [PRO INNO Europe®]. European Union 2012. ISBN 978-92-79-23174-2. http://ec.europa.eu/enterprise/policies/innovation/files/ius-2011_en.pdf

EUROPEAN COMISSION. (2011). Lessons from a Decade of Innovation Policy What can be learnt from the INNO Policy TrendChart and The Innovation Union Scoreboard - Executive Summary.

EUROPEAN COMISSION. (2013). Research and Innovation Performance in Slovakia Country Profile. Luxembourg: Publications Office of the European Union. ISBN 97892-79-30866-6.

GEOGHEGAN-QUINN, M. (2010). Address by Commissioner Máire GeogheganQuinn to the Joint Oireachtas Committee on European Affairs. Príspevok prezentovaný pred Joint Oireachtas Committee on European Affairs, Dublin, 2010. http://ec.europa.eu/ireland/press_office/speeches-press_releases/maire-geogheganquinn-speech-european-affairs-committee_en.htm

GRIFFITH, R. (2000). How important is business R\&D for economic growth and should the government subsidise it? London: Institue for Fiscal studies, 2000. ISBN 1 903274-13-3.

GROSSMAN, G. M.; HELPMAN, E. (1994). Endogenous Innovation in the Theory of Growth. The Journal of Economic Perspectives. 1994. Vol. 8, No. 1, pp. 23-44.

HERRERA L.; IBARRA B. (2010). Distribution and effect of R\&D subsidies: A comparative analysis according to firm size. Intangible capital. 2010. Vol. 6, No. 2, pp. 272299. 
HESHMATI, A.; LOOF, H. (2005). The impact of public funds on private R\&D investment. New evidence from a firm level innovation study [MTT Discussion Papers 3 11682] Agrifood Research Finland. 2005.

HULYA, U. (2004). R\&D, innovation, and economic growth : an empirical analysis [Working Paper No. 04/185] International Monetary Fund: Research department, 2004.

JONES, C. (1995). R\&D based model of economic growth. Journal of political economy. 1995, Vol. 103, No. 4, pp. 759-784.

JONES C.; WILIAMS J. (2000). Too Much of a Good Thing? The Economics of Investment in R\&D . Journal of Economic Growth. 2000, Vol. 5, No.1, pp. 65-85.

KOTULIČ, R. (2006). Foreign Direct Investments and Their Influence on Economic Growth and Regional Development. Review of Economic Perspectives. 2006. No. 2, pp. 15-25. ISSN: ISSN 1804-1663.

KUNCL, M. (2010). Cesta k obnově růstu: inovace, pracovní místa a čistý růst (globální fórum OECD 2010 v Paříži). Politická ekonomie. 2010, Vol. 48, No. 6, pp. 830 - 837.

LACH S. (2002). Do R\&D subsidies stimulate or displace private R\&D? Evidence from Israel. The journal of industrial economics. 2002, Vol. 50, No. 4, pp. 369-390.

LEVIN, R. C., KLEVORICK, A. K., NELSON, R. R., WINTER, S. G. (1987). Appropriating the Returns from Industrial Research and Development. Brookings Papers on Economic Activity. 1987, Vol. 3, pp. 783-832.

LUCAS R. (1988). On the mechanics of economic development. Journal of monetary economics. 1988. Vol. 22, No.1, pp. 3-42.

MANSFIELD, E.; SCHWARTZ, M.; WAGNER, S. (1981). Imitation Costs and Patents: An Empirical Study. Economic Journal. 1981, Vol. 91, pp. 907-918.

MINISTRY OF FINANCE OF THE SLOVAK REPUBLIC. (2011). Minerva 2.0 Slovensko do prvej ligy. Uznesenie vlády Slovenskej republiky.

MINISTRY OF FINANCE OF THE SLOVAK REPUBLIC. (2014). Čerpanie štrukturálnych fondov, Kohézneho fondu a Európskeho fondu pre rybné hospodárstvo $\mathrm{k}$ 31.12.2013.

MINISTRY OF ECONOMY OF THE SLOVAK REPUBLIC. (2007). Inovačná stratégia SR na roky 2007 až 2013.

MINISTRY OF EDUCATION, SCIENCE, RESEARCH AND SPORT OF THE SLOVAK REPUBLIC. (2010). Dlhodobý zámer štátnej vednej a technickej politiky do roku 2015.

PESSOA, A. (2010). R\&D and economic growth: How strong is the link? Economic Letters. 2010, Vol. 107, No. 2, pp. 152-154.

PRNO, I. (2008). Investičná a inovačná politika. Bratislava : Merkury s.r.o, 2008. 218 s. ISBN 978-80-89143-85-6.

ROMER, P. (1990). Endogenous technological change. Journal of Political Economy. 1990, Vol. 5, No. 98, pp. 71-102. 
SEGERSTROM, P.S.; T. C. A. ANANT, T., C., A.; DINOPOUlOS,. (1990). A Schumpeterian Model of the Product Life Cycle. The American Economic Review. 1990, Vol. 80, No. 5, pp. 1077-1091.

Science and Technology Policy (n.d.). Retrieved July 17, 2014, from http://sovva.sk/science-and-technology-policy

ÚRAD VLÁDY SLOVENSKEJ REPUBLIKY. 2010. Lisabonská stratégia a Slovensko. 2010.

ZACHARIADIS M. (2004). R\&D, innovation, and technological progress: a test of the Schumpeterian framework without scale effects. Canadian Journal of Economics. 2003, Vol. 36, No.3, pp. 566-586.

ZEMPLINEROVÁ, A. (2010). Inovační aktivita firem a konkurence. Politická ekonomie. 2010, Vol. 58, No. 6, pp. 747-760.

ZENG J. (2000). Innovative vs. imitative R\&D and economic growth. Journal of Development economics. 2000, Vol. 64, No. 2, pp. 499-528. 